\title{
Clinical Practice Guidelines by the Infectious Diseases Society of America, American Academy of Neurology, and American College of Rheumatology
}

\author{
2020 Guidelines for the Prevention, Diagnosis, and Treatment of Lyme Disease
}

Paul M. Lantos, MD, Jeffrey Rumbaugh, MD, Linda K. Bockenstedt, MD, Yngve T. Falck-Ytter, MD,

Maria E. Aguero-Rosenfeld, MD, Paul G. Auwaerter, MD, Kelly Baldwin, MD,

Raveendhara R. Bannuru, MD, PhD, FAGE, Kiran K. Belani, MD, William R. Bowie, MD, John A. Branda, MD,

David B. Clifford, MD, Francis J. DiMario, Jr., MD, John J. Halperin, MD, Peter J. Krause, MD,

Valery Lavergne, MD, MSc, FRCPC, Matthew H. Liang, MD, MPH, H. Cody Meissner, MD,

Lise E. Nigrovic, MD, MPH, James (Jay) J. Nocton, MD, Mikala C. Osani, Amy A. Pruitt, MD, Jane Rips,

Lynda E. Rosenfeld, MD, Margot L. Savoy, MD, MPH, Sunil K. Sood, MD, Allen C. Steere, MD,

Franc Strle, MD, PhD, Robert Sundel, MD, Jean Tsao, MS, PhD, Elizaveta E. Vaysbrot, Gary P. Wormser, MD, and

Lawrence S. Zemel, MD

Neurology ${ }^{\circledR}$ 2021;96:262-273. doi:10.1212/WNL.0000000000011151

\begin{abstract}
This evidence-based clinical practice guideline for the prevention, diagnosis, and treatment of Lyme disease was developed by a multidisciplinary panel representing the Infectious Diseases Society of America (IDSA), the American Academy of Neurology (AAN), and the American College of Rheumatology (ACR). The scope of this guideline includes prevention of Lyme disease, and the diagnosis and treatment of Lyme disease presenting as erythema migrans, Lyme disease complicated by neurologic, cardiac, and rheumatologic manifestations, Eurasian manifestations of Lyme disease, and Lyme disease complicated by coinfection with other tickborne pathogens. This guideline does not include comprehensive recommendations for babesiosis and tick-borne rickettsial infections, which are published in separate guidelines. The target audience for this guideline includes primary care physicians and specialists caring for this condition such as infectious diseases specialists, emergency physicians, internists, pediatricians, family physicians, neurologists, rheumatologists, cardiologists and dermatologists in North America.
\end{abstract}

Correspondence

Dr. P. M. Lantos

paul.lantos@duke.edu

MORE ONLINE

ค Podcast

Dr. Jason Crowell interviews Dr. Jeffrey Rumbaugh about the latest Lyme Disease Guidelines.

NPub.org/97y4c5

From the Duke University School of Medicine (P.M.L.), Durham, NC; Pathway Neurology (J. Rumbaugh), Tampa, FL; Yale University (L.K.B., L.E.R.), New Haven, CT; Case Western Reserve University, VA Northeast Ohio Healthcare System (Y.T.F.-Y.), Cleveland; New York University School of Medicine (M.E.A.-R.), New York; Johns Hopkins University School of Medicine (P.G.A.), Baltimore, MD; Geisinger Medical Center (K.B.), Danville, PA: Tufts Medical Center (R.R.B., H.C.M., M.C.O., E.E.V.). Boston, MA; Childrens Hospital and Clinical of Minnesota (K.K.B.), Minneapolis; University of British Columbia (W.R.B.), Vancouver Canada; Massachusetts General Hospital (J.A.B., A.C.S.), Boston; Washington University School of Medicine (D.B.C.), St. Louis, Missouri; Connecticut Children's Medical Center (F.J.D.M., L.S.Z.), Hartford, CT; Atlantic Health System (.J.H.), Summit, NJ; Yale School of Public Health (P.J.K.), New Haven, CT; University of Montreal (V.L.), Quebec, Canada; Brigham and Women's Hospital (M.H.L.), Boston, MA; Boston Children's Hospital (L.E.N., R.S.), Massachusetts; Medical College of Wisconsin (J.(.).).N.), Waowatosa; University of Pennsylvania (A.A.P.), Philadelphia; Consumer Representative (J. Rips), Omaha, NE; Temple University (M.L.S.), Philadelphia, PA; Northwell Health (S.K.S.), New York, NY; University Medical Centre Ljubljana (F.S.), Slovenia; Michigan State University (I.T.), East Lansing; and New York Medical College (G.P.W.), Valhalla.

Full disclosures only appear within the published guideline. Neurology did not facilitate the collection of competing interests. Funding information and disclosures are provided at the end of the article.

This guideline was jointly developed by the Infectious Diseases Society of America, the American Academy of Neurology Institute, and the American College of Rheumatology. The article was peer reviewed by Arthritis \& Rheumatology and simultaneously published by Clinical Infectious Diseases, Neurology, Arthritis Care \& Research, and Arthritis \& Rheumatology. Each editor of the 4 journals appointed 1 reviewer for peer review. The articles are identical except for minor stylistic and spelling differences in keeping with each journal's style. The full guideline is available at: https://www.aan.com/Guidelines/home/GuidelineDetail/1015.

Approved by the AAN Guideline Subcommittee on February 20, 2020; by the AAN Quality Committee on February 25, 2020; by the AAN Institute Board of Directors on March 5, 2020; by the Infectious Diseases Society of America Board of Directors on June 23, 2020; and by the American College of Rheumatology Board of Directors on June 11, 2020. 
Summarized below are the 2020 recommendations for the prevention, diagnosis, and treatment of Lyme disease. The panel followed a systematic process used in the development of other Infectious Diseases Society of America (IDSA), American Academy of Neurology (AAN), and American College of Rheumatology (ACR) clinical practice guidelines, which included a standardized methodology for rating the certainty of the evidence and strength of recommendation using the Grading of Recommendations Assessment, Development, and Evaluation (GRADE) approach (figure). A detailed description of background, methods, evidence summary and rationale that support each recommendation, and knowledge gaps can be found online in the full text (https:// www.aan.com/Guidelines/home/GuidelineDetail/1015).

\section{Which Measures Should Be Used to Prevent Tick Bites and Tick-Borne Infections?}

\section{(A) Personal Protective Measures}

\section{Recommendation}

1. Individuals at risk of exposure should implement personal protective measures to reduce the risk of tick exposure and infection with tick-borne pathogens (good practice statement).

\section{(B) Repellents to Prevent Tick Bites}

\section{Recommendation}

1. For the prevention of tick bites, we recommend N,Ndiethyl-meta-toluamide (DEET), picaridin, ethyl-3-(N-nbutyl-N-acetyl)aminopropionate (IR3535), oil of lemon eucalyptus (OLE), p-menthane-3,8-diol (PMD), 2-undecanone, or permethrin (strong recommendation, moderate-quality evidence).

\section{(C) Removal of Attached Ticks}

\section{Recommendations}

1. We recommend promptly removing attached ticks by mechanical means using a clean fine-tipped tweezer (or a comparable device) inserted between the tick body and the skin (good practice statement).

2. We recommend against burning an attached tick (with a match or other heat device) or applying noxious chemicals or petroleum products to coax its detachment (good practice statement).

\section{Which Diagnostic Tests Should Be Used Following a Tick Bite?}

\section{(A) Diagnostic Tick Testing}

\section{Recommendations}

1. We recommend submitting the removed tick for species identification (good practice statement).
2. We recommend against testing a removed Ixodes tick for Borrelia burgdorferi (strong recommendation, moderate-quality evidence). Comment: The presence or absence of $B$ burgdorferi in an Ixodes tick removed from a person does not reliably predict the likelihood of clinical infection.

\section{(B) Diagnostic Testing of Asymptomatic} Patients Following Tick Bites

\section{Recommendation}

1. We recommend against testing asymptomatic patients for exposure to $B$ burgdorferi following an Ixodes spp. tick bite (strong recommendation, moderate-quality evidence).

\section{Who Should Receive Antibiotic Prophylaxis to Prevent Lyme Disease Following Presentation With a Tick Bite?}

\section{Recommendation}

1. We recommend that prophylactic antibiotic therapy be given only to adults and children within 72 hours of removal of an identified high-risk tick bite, but not for bites that are equivocal risk or low risk (strong recommendation, high-quality evidence). Comment: If a tick bite cannot be classified with a high level of certainty as a highrisk bite, a wait-and-watch approach is recommended. A tick bite is considered to be high risk only if it meets the following 3 criteria: the tick bite was from (a) an identified Ixodes spp. vector species, (b) it occurred in a highly endemic area, and (c) the tick was attached for $\geq 36$ hours.

\section{What Is the Preferred Antibiotic Regimen for the Chemoprophylaxis of Lyme Disease Following a High-Risk Tick Bite?}

\section{Recommendation}

1. For high-risk Ixodes spp. bites in all age groups, we recommend the administration of a single dose of oral doxycycline within 72 hours of tick removal over observation (strong recommendation, moderate-quality evidence). Comment: Doxycycline is given as a single oral dose, $200 \mathrm{mg}$ for adults and $4.4 \mathrm{mg} / \mathrm{kg}$ (up to a maximum dose of $200 \mathrm{mg}$ ) for children.

\section{What Is the Preferred Diagnostic Testing Strategy for Erythema Migrans?}

\section{Recommendations}

1. In patients with potential tick exposure in a Lyme disease endemic area who have 1 or more skin lesions compatible with erythema migrans, we recommend clinical diagnosis 
rather than laboratory testing (strong recommendation, moderate quality evidence).

2. In patients with 1 or more skin lesions suggestive of, but atypical for erythema migrans, we suggest antibody testing performed on an acute-phase serum sample (followed by a convalescent-phase serum sample if the initial result is negative) rather than currently available direct detection methods such as PCR or culture performed on blood or skin samples (weak recommendation, low-quality evidence). Comment: If needed, the convalescent-phase serum sample should be collected at least $2-3$ weeks after collection of the acute-phase serum sample.

\section{What Are the Preferred Antibiotic Regimens for the Treatment of Erythema Migrans?}

\section{Recommendation}

1. For patients with erythema migrans, we recommend using oral antibiotic therapy with doxycycline, amoxicillin, or cefuroxime axetil (strong recommendation; moderate quality of evidence). Comment: For patients unable to take both doxycycline and beta-lactam antibiotics, the preferred secondline agent is azithromycin.

\section{How Long Should a Patient With Erythema Migrans Be Treated?}

\section{Recommendation}

1. We recommend that patients with erythema migrans be treated with either a 10-day course of doxycycline or a 14-day course of amoxicillin or cefuroxime axetil rather than longer treatment courses (strong recommendation, moderate quality of evidence). Comment: If azithromycin is used, the indicated duration is 5-10 days, with a 7-day course preferred in the United States, as this duration of therapy was used in the largest clinical trial performed in the United States. ${ }^{3}$

\section{Should Patients With the Southern Tick-Associated Rash Illness (STARI) Be Treated With Antibiotics?}

\section{Recommendation}

1. In patients who develop an erythema migrans-like skin lesion following the bite of the lone star tick (Amblyomma americanum), an illness referred to as STARI, we make no recommendation for or against the use of antibiotics (no recommendation; knowledge gap). Comment: In certain geographic regions, both STARI and Lyme disease are endemic. ${ }^{4}$ Distinguishing single erythema migrans due to Lyme disease from STARI may not be possible clinically unless the responsible tick has been identified. ${ }^{5}$ When STARI cannot be distinguished from Lyme disease-associated erythema migrans in areas endemic for both conditions, antibiotic therapy directed toward Lyme disease is indicated.

\section{What Is the Preferred Diagnostic Testing Strategy for Lyme Neuroborreliosis?}

\section{Recommendations}

1. When assessing patients for possible Lyme neuroborreliosis involving either the PNS or the CNS, we recommend serum antibody testing rather than PCR or culture of either CSF or serum (strong recommendation, moderate-quality of evidence).

2. If CSF testing is performed in patients with suspected Lyme neuroborreliosis involving the CNS, we (a) recommend obtaining simultaneous samples of CSF and serum for determination of the CSF:serum antibody index, performed by a laboratory using validated methodology, (b) recommend against CSF serology without measurement of the CSF:serum antibody index, and (c) recommend against routine PCR or culture of CSF or serum (strong recommendation, moderate-quality of evidence).

\section{For Which Neurologic Presentations Should Patients Be} Tested for Lyme Disease?

\section{Recommendations}

1. In patients presenting with 1 or more of the following acute disorders: meningitis, painful radiculoneuritis, mononeuropathy multiplex including confluent mononeuropathy multiplex, acute cranial neuropathies (particularly VII and VIII and less commonly III, V, VI, and others), or in patients with evidence of spinal cord (or rarely brain) inflammation, the former particularly in association with painful radiculitis involving related spinal cord segments, and with epidemiologically plausible exposure to ticks infected with $B$ burgdorferi, we recommend testing for Lyme disease (strong recommendation, moderate-quality evidence).

2. In patients with typical amyotrophic lateral sclerosis, relapsing-remitting multiple sclerosis, Parkinson disease, dementia or cognitive decline, or new-onset seizures, we recommend against routine testing for Lyme disease (strong recommendation, low-quality evidence).

3. In patients with neurologic syndromes other than those listed in (1) or (2), in the absence of a history of other clinical or epidemiologic support for the diagnosis of Lyme disease, we recommend against screening for 
Lyme disease (strong recommendation, low-quality evidence).

4. In patients presenting with nonspecific MRI white matter abnormalities confined to the brain in the absence of a history of other clinical or epidemiologic support for the diagnosis of Lyme disease, we suggest against testing for Lyme disease (weak recommendation, low-quality evidence).

\section{Should Adult Patients With}

Psychiatric Illnesses Be Tested for

\section{Lyme Disease?}

\section{Recommendation}

1. In patients with psychiatric illness, we recommend against routine testing for Lyme disease (strong recommendation, low-quality evidence).

\section{Should Children With Developmental, Behavioral, or Psychiatric Disorders Be Tested for Lyme Disease?}

\section{Recommendation}

1. In children presenting with developmental, behavioral, or psychiatric disorders, we suggest against routinely testing for Lyme disease (weak recommendation, low-quality evidence).

\section{What Are the Preferred Antibiotic Regimens for the Treatment of Acute Neurologic Manifestations of Lyme Disease Without Parenchymal Involvement of the Brain or Spinal Cord?}

\section{Recommendation}

1. In patients with Lyme disease-associated meningitis, cranial neuropathy, radiculoneuropathy, or with other peripheral nervous system (PNS) manifestations, we recommend using IV ceftriaxone, cefotaxime, penicillin $\mathrm{G}$, or oral doxycycline over other antimicrobials (strong recommendation, moderate-quality evidence). Comment: Decisions about the choice of antibiotic among these, including the route of administration, should primarily be made based on individual factors such as side effect profile, ease of administration, ability to tolerate oral medication, and concerns about compliance unrelated to effectiveness. Treatment route may be changed from IV to oral during treatment. The preferred antibiotic duration is 14-21 days.
XIV. Should Patients With Lyme

Disease-Related Parenchymal

Involvement of the Brain or Spinal

Cord Be Treated With Oral or

IV Antibiotics?

\section{Recommendation}

1. In patients with Lyme disease-associated parenchymal involvement of the brain or spinal cord, we recommend using IV over oral antibiotics (strong recommendation, moderate-quality evidence).

XV. Should Patients With Lyme

Disease and Facial Nerve Palsy

Receive Corticosteroids in Addition to Antimicrobial Therapy?

\section{Recommendation}

1. In patients with Lyme disease-associated facial nerve palsy, we make no recommendation on the use of corticosteroids in addition to antibiotics (no recommendation; knowledge gap). Comment: In patients aged 16 years or older presenting with acute facial nerve palsy but without other objective clinical or serologic evidence of Lyme disease, corticosteroid treatment should be administered within 72 hours in accordance with current facial nerve palsy guideline recommendations. ${ }^{6}$

\section{Should All Patients With Early}

Lyme Disease Receive an ECG to Screen for Lyme Carditis?

\section{Recommendation}

1. We suggest performing an ECG only in patients with signs or symptoms consistent with Lyme carditis (weak recommendation, low-quality evidence). Comment: Symptoms and signs of cardiac involvement in Lyme disease include dyspnea, edema, palpitations, lightheadedness, chest pain, and syncope.

\section{Which Patients With Lyme Carditis Require Hospitalization?}

\section{Recommendation}

1. In patients with or at risk of severe cardiac complications of Lyme disease including those with significant $\mathrm{PR}$ prolongation (PR > 300 milliseconds), other arrhythmias, or clinical manifestations of myopericarditis, we recommend hospital admission with continuous ECG monitoring (strong recommendation, very-low-quality evidence). Comment: Clinical manifestations of Lyme carditis include exercise intolerance, palpitations, presyncope, syncope, pericarditic pain, evidence of pericardial effusion, elevated biomarkers (such as troponin), edema, and shortness of breath. 
Figure Approach and Implications to Rating the Quality of Evidence and Strength of Recommendations Using the GRADE Methodology (Unrestricted use of the Figure Granted by the US GRADE Network) $)^{1,2}$

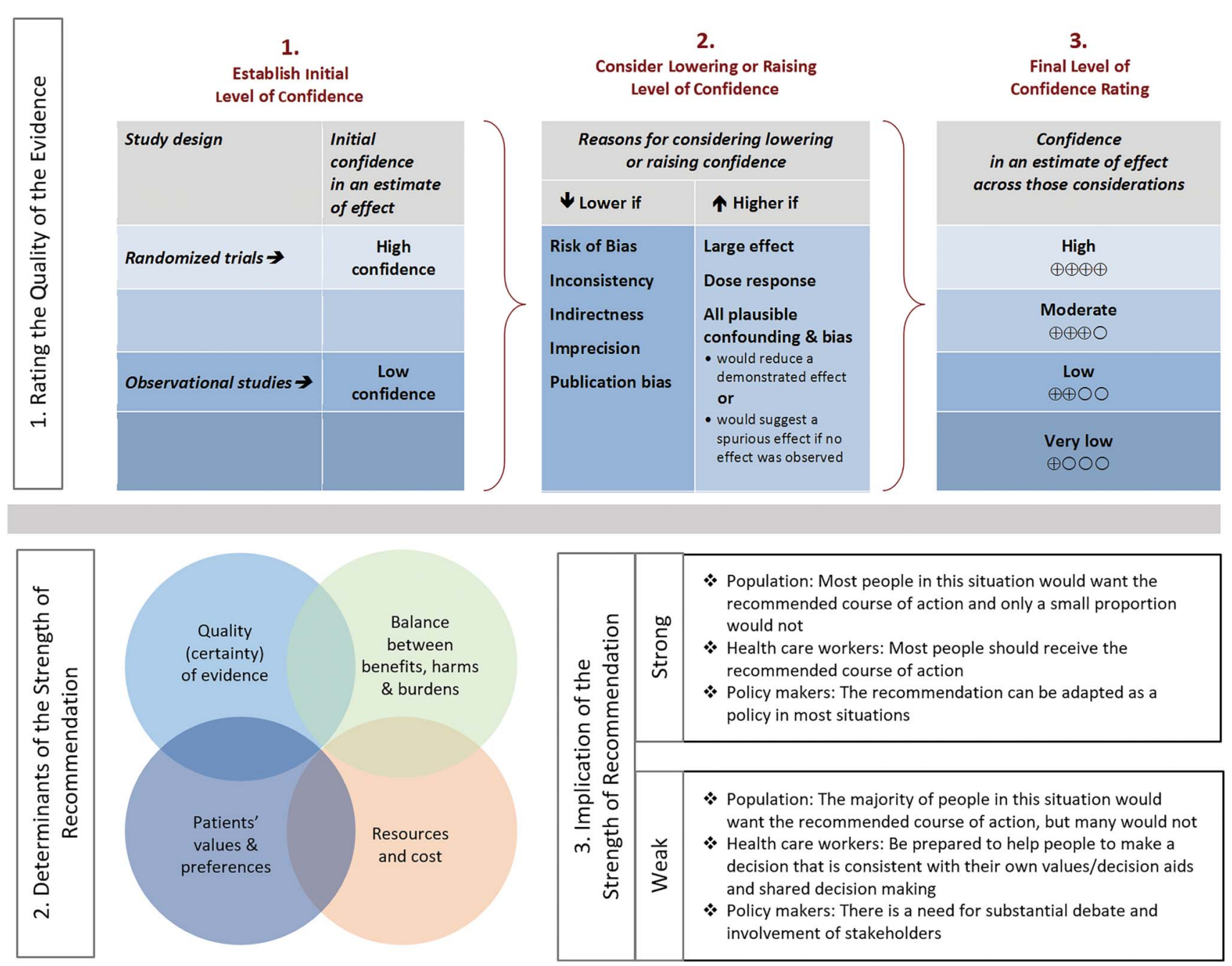

GRADE = Grading of Recommendations Assessment, Development, and Evaluation.

XVIII. What Pacing Modality Should

Be Used if Needed for the

\section{Management of Lyme Carditis?}

\section{Recommendation}

1. For patients with symptomatic bradycardia due to Lyme carditis that cannot be managed medically, we recommend temporary pacing modalities rather than implanting a permanent pacemaker (strong recommendation, moderate-quality evidence).

\section{What Are the Preferred Antibiotic Regimens for the Treatment of Lyme Carditis?}

\section{Recommendations}

1. In outpatients with Lyme carditis, we suggest oral antibiotics over IV antibiotics (weak recommendation, very-low-quality evidence).
2. In the hospitalized patient with Lyme carditis, we suggest initially using IV ceftriaxone over oral antibiotics until there is evidence of clinical improvement and then switching to oral antibiotics to complete treatment (weak recommendation, very-low-quality evidence).

3. For the treatment of Lyme carditis, we suggest 14-21 days of total antibiotic therapy over longer durations of treatment (weak recommendation, very-low-quality evidence). Comment: Oral antibiotic choices for Lyme carditis are doxycycline, amoxicillin, cefuroxime axetil, and azithromycin.

\section{Should Patients Being Evaluated for} Acute Myocarditis/Pericarditis or Chronic Cardiomyopathy of Unknown

\section{Cause Be Tested for Lyme Disease?}

\section{Recommendations}

1. In patients with acute myocarditis/pericarditis of unknown cause in an appropriate epidemiologic setting, we 
recommend testing for Lyme disease (strong recommendation, low-quality evidence).

2. In patients with chronic cardiomyopathy of unknown cause, we suggest against routine testing for Lyme disease (weak recommendation, low-quality evidence).

\section{What Is the Preferred Diagnostic Testing Strategy for Lyme Arthritis?}

\section{Recommendations}

1. When assessing possible Lyme arthritis, we recommend serum antibody testing over PCR or culture of blood or synovial fluid/tissue (strong recommendation, moderate quality of evidence).

2. In seropositive patients for whom the diagnosis of Lyme arthritis is being considered but treatment decisions require more definitive information, we recommend PCR applied to synovial fluid or tissue rather than Borrelia culture of those samples (strong recommendation, moderate quality of evidence).

\section{What Are the Preferred Antibiotic Regimens for the Initial Treatment of Lyme Arthritis?}

\section{Recommendation}

1. For patients with Lyme arthritis, we recommend using oral antibiotic therapy for 28 days (strong recommendation, moderate-quality evidence).

\section{What Are the Approaches to Patients in Whom Lyme Arthritis Has Not Completely Resolved?}

\section{Recommendations}

1. In patients with Lyme arthritis with partial response (mild residual joint swelling) after a first course of oral antibiotic, we make no recommendation for a second course of antibiotic vs observation (no recommendation, knowledge gap). Comment: Consideration should be given to exclusion of other causes of joint swelling than Lyme arthritis, medication adherence, duration of arthritis before initial treatment, degree of synovial proliferation vs joint swelling, patient preferences, and cost. A second course of oral antibiotics for up to 1 month may be a reasonable alternative for patients in whom synovial proliferation is modest compared with joint swelling and for those who prefer repeating a course of oral antibiotics before considering IV therapy.

2. In patients with Lyme arthritis with no or minimal response (moderate to severe joint swelling with minimal reduction of the joint effusion) to an initial course of oral antibiotic, we suggest a 2- to 4-week course of IV ceftriaxone over a second course of oral antibiotics (weak recommendation, low-quality evidence).
XXIV. How Should Postantibiotic

(Previously Termed Antibiotic-

\section{Refractory) Lyme Arthritis}

\section{Be Treated?}

\section{Recommendation}

1. In patients who have failed 1 course of oral antibiotics and 1 course of IV antibiotics, we suggest a referral to a rheumatologist or other trained specialist for consideration of the use of diseasemodifying antirheumatic drugs (DMARDs), biologic agents, intra-articular steroids, or arthroscopic synovectomy (weak recommendation, very-low-quality evidence). Comment: Antibiotic therapy for longer than 8 weeks is not expected to provide additional benefit to patients with persistent arthritis if that treatment has included 1 course of IV therapy.

\section{Should Patients With Persistent Symptoms Following Standard Treatment of Lyme Disease Receive Additional Antibiotics?}

\section{Recommendation}

1. For patients who have persistent or recurring nonspecific symptoms such as fatigue, pain, or cognitive impairment following recommended treatment for Lyme disease, but who lack objective evidence of reinfection or treatment failure, we recommend against additional antibiotic therapy (strong recommendation, moderate-quality evidence). Comment: Evidence of persistent infection or treatment failure would include objective signs of disease activity, such as arthritis, meningitis, or neuropathy.

\section{What Is the Preferred Antibiotic Regimen for the Treatment of Borrelial Lymphocytoma?}

\section{Recommendation}

1. In patients with borrelial lymphocytoma, we suggest oral antibiotic therapy for 14 days (weak recommendation, low-quality evidence).

\section{What Is the Preferred Antibiotic Regimen for the Treatment of Acrodermatitis \\ Chronica Atrophicans?}

\section{Recommendation}

1. In patients with acrodermatitis chronica atrophicans, we suggest oral antibiotic therapy for 21-28 days over shorter durations (weak recommendation, low-quality evidence). 


\section{Under What Circumstances Should a Patient With Lyme Disease Be Evaluated for Coinfection With Anaplasma Phagocytophilum or Babesia Microti?}

\section{Recommendation}

1. In patients with Lyme disease who have a high-grade fever or characteristic laboratory abnormalities, clinicians should assess for possible coinfection with A phagocytophilum and/ or $B$ microti infection in geographic regions where these infections are endemic (good practice statement). Comment: Coinfection should be investigated in patients who have a persistent fever for $>1$ day while on antibiotic treatment for Lyme disease. If fever persists despite treatment with doxycycline, $B$ microti infection is an important consideration. Characteristic laboratory abnormalities found in both anaplasmosis and babesiosis include thrombocytopenia, leukopenia, neutropenia, and/or anemia. Evidence of hemolysis such as elevated indirect bilirubin level, anemia, and elevated lactate dehydrogenase is particularly suggestive of babesiosis.

\section{Supplementary Data}

Supplementary materials are available at Clinical Infectious Diseases online. Consisting of data provided by the authors to benefit the reader, the posted materials are not copyedited and are the sole responsibility of the authors, so questions or comments should be addressed to the corresponding author.

\section{Disclaimer}

It is important to realize that guidelines cannot always account for individual variation among patients. They are assessments of current scientific and clinical information provided as an educational service; are not continually updated and may not reflect the most recent evidence (new evidence may emerge between the time information is developed and when it is published or read); should not be considered inclusive of all proper treatments methods of care or as a statement of the standard of care; do not mandate any particular course of medical care; and are not intended to supplant physician judgment with respect to particular patients or special clinical situations. Whether and the extent to which to follow guidelines is voluntary, with the ultimate determination regarding their application to be made by the physician in the light of each patient's individual circumstances. Although the IDSA, AAN, and ACR make every effort to present accurate, complete, and reliable information, these guidelines are presented as is without any warranty, either expressed or implied. The IDSA, AAN, and ACR (and their officers, directors, members, employees, and agents) assume no responsibility for any loss, damage, or claim with respect to any liabilities, including direct, special, indirect, or consequential damages, incurred in connection with these guidelines or reliance on the information presented.

The guidelines represent the proprietary and copyrighted property of the IDSA, AAN, or ACR. Copyright 2020 Infectious Diseases Society of America, American Academy of Neurology, and American College of Rheumatology. All rights reserved. No part of these guidelines may be reproduced, distributed, or transmitted in any form or by any means, including photocopying, recording, or other electronic or mechanical methods, without the prior written permission of the IDSA, AAN, and ACR. Permission is granted to physicians and health care providers solely to copy and use the guidelines in their professional practices and clinical decision making. No license or permission is granted to any person or entity, and prior written authorization by IDSA, AAN, or ACR is required, to sell, distribute, or modify the guidelines, or to make derivative works of or incorporate the guidelines into any product, including but not limited to clinical decision support software or any other software product. Except for the permission granted above, any person or entity desiring to use the guidelines in any way must contact the IDSA, AAN, or ACR for approval in accordance with the terms and conditions of third party use, in particular any use of the guidelines in any software product.

\section{Acknowledgment}

The expert panel expresses its gratitude for thoughtful reviews of an earlier version to the external reviewers. The panel thanks the IDSA, AAN, and ACR for supporting the guideline development process.

\section{Study Funding}

Support for this guideline was provided by the Infectious Diseases Society of America, the American Academy of Neurology, and the American College of Rheumatology.

\section{Disclosure}

See the Methodology section for approach to COI by the IDSA/ AAN/ACR COI review group. The following list is a reflection of what has been reported to the IDSA/AAN/ACR COI review group. To provide thorough transparency, the IDSA/AAN/ ACR requires full disclosure of all relationships, regardless of relevancy to the guideline topic. The assessment of disclosed relationships for possible COI is based on the relative weight of the financial relationship (i.e., monetary amount) and the relevance of the relationship (i.e., the degree to which an association might reasonably be interpreted by an independent observer as related to the topic or recommendation of consideration). The reader of these guidelines should be mindful of this when the list of disclosures is reviewed. M. A. R. serves as a council member for the New York City chapter of the American Society of Microbiology (ASM) and as a board member of the American Lyme Disease Foundation; has provided legal testimony and consultation regarding Lyme disease and tick-borne diseases; and has received research grants from the NIH, BioFire, New York State Department of Health, and ViraMed. P. G. A. receives research funding from the Fisher Center for Environmental 
Infectious Diseases and the NIH; serves on the Board of Directors of the American Lyme Disease Foundation and as the Vice Chair of the Infectious Diseases Society of America (IDSA) Foundation; serves as a scientific advisor for DiaSorin, Adaptive Technologies, and Shionogi; provides legal expert opinion testimony regarding Lyme disease; had stock in Johnson \& Johnson; has served as an editor for John Hopkins POC-IT ABX Guide and an advisor for the Food and Drug Administration (FDA), Genentech, Dynavax, Aradigm, Cempra, BioMérieux, Cerexa, and Medscape; has received research funding from Cerexa; has served on the FDA Advisory Board, the Medscape Advisory Board, and the IDSA Board of Directors; and his spouse has equity interest in venture capital-funded Capricor. $\mathrm{K}$. $\mathrm{K}$. B. reviews noncontinuing medical education (CME) lectures for and received honoraria and travel reimbursement from Horizon Therapeutics and has received research funding from the $\mathrm{NIH}$ and the Children's Hospitals and Clinics of Minnesota. L. $\mathrm{K}$. B. receives research funding from the NIH and the Gordon and the Llura Gund Foundation; has received research funding from the NIH and the Gordon and Llura Gund Foundation; has received remuneration from L2 Diagnostics for investigatorinitiated NIH-sponsored research; and was awarded an endowed professorship as the Harold W. Jockers Professor of Medicine at Yale University. W. R. B. has provided expert testimony to the Canadian Senate Subcommittee on Bill C-442: An Act Respecting a National Lyme Disease Strategy on behalf of the Association of Medical Microbiology and Infectious Disease Canada and has received research funding from GlaxoSmithKline, Pfizer Canada, the Canadian Institutes of Health Research, and Vancouver Coastal Health Research Institute. J. A. B. receives research funding from the Lyme Disease Biobank Foundation and Zeus Scientific; serves as a scientific advisor and consultant to DiaSorin, Inc.; has served as a scientific advisor and consultant for T2 Biosystems; has served on the scientific advisory board of Roche Diagnostics and AdvanDx; has received research funding from Karius, Inc., Alere, Inc., T2 Biosystems, BioMérieux, TBS Technologies, Immunetics, Inc., DiaSorin, Inc., Kephera Diagnostics, Inc., and the Bay Area Lyme Foundation; has participated in unfunded research collaborations with Karius Inc. and Kephera Diagnostics; was a member of the editorial board of the Journal of Clinical Microbiology; was a coinventor on an application for a patent to protect intellectual property; and his spouse is an employee of Informed DNA. D. B. C. receives research funding from the NIH and the Alzheimer's Association; serves as scientific consultant to Inhibikase and Excision BioTherapeutics; serves on Data and Safety Monitoring Boards (DSMB) for Biogen, Genzyme/Sanofi, Genentech, EMD Serono, Shire, Wave Life Sciences, Pfizer, Atara, and Mitsubishi Tanabe and IQVIA (formerly Quintiles); serves on Progressive Multifocal Leukoencephalopathy (PML) adjudication committees for Amgen, GlaxoSmithKline, EMD Serono, Bristol-Myers Squibb, Roche, and the Takeda Oncology (formerly Millennium) Adjudication Committee-FDA, as well as Dr. Reddy's Laboratories; has previously received research funding from the $\mathrm{NIH}$; and his spouse formerly held stock in Johnson \& Johnson. F. J. D. has received research funding from Novartis. Y. F. Y. serves as director of the Evidence Foundation and the GRADE Network; conducts GRADE workshops with the Evidence Foundation; has served as the chair of the Guidelines Committee for the American Gastroenterological Association; and has received research funding from the Cleveland VA Medical Research and Education Foundation. J. J. H. serves as an Editorial Board Member of Neurology and Vice Chair of the American Academy of Neurology (AAN) Guideline Subcommittee; has stock in Abbott Labs, AbbVie, Merck, and Johnson \& Johnson; provides and has previously provided legal expert testimony defending physicians in medical malpractice cases on various neurologic issues, including Lyme disease; has received research funding from the NIH and the Centers for Disease Control and Prevention (CDC); and has served as a section editor of neuroinfectious diseases in Neurology \& Neuroscience Reports. P. J. K. receives research funding from the NIH, the Gordon and Llura Gund Foundation, and the Yale Emerging Infections Program; receives remuneration from Gold Standard Diagnostics for a collaborative research project; has stock in Gilead Sciences and First Trust NASDAQ Pharmaceuticals ETF; has received research funding from $\mathrm{NIH}$, the Centers for Disease Control and Prevention (CDC), the Gordon and Llura Gund Foundation, and L2 Diagnostics for NIH-sponsored research; has served as a scientific consultant and provided medical education and training for Oxford Immunotec, Inc.; has a patent pending (Enhanced chemiluminescent enzyme-linked immunosorbent assay for detection of antibodies against Babesia microti), for which U.S. Provisional Patent Application No. 62/ 580,588, was filed on November 2, 2017; serves on the Board of Directors for the American Lyme Disease Foundation and the Editorial Boards of Pathogens and PLOS Neglected Tropical Diseases, the Editorial Advisory Board of Clinical Infectious Diseases; was on the Editorial Board of the Journal of Clinical Microbiology, and will be on the Editorial Board of Clinical Microbiology Reviews starting January 2021. P. M. L. has received research funding from the National Cytomegalovirus Foundation and from the NIH and educational funding from Duke University and has served as a consultant and reviewed trial protocol for Frederick O'Connor Medical Consultants, LLC. M. H. L. has stock in Johnson \& Johnson; received research funding from the Veterans Health Administration, the Arthritis Foundation, and the NIH; has served on the FDA Advisory Panel and Institute of Medicine panels; served as a scientific reviewer for the Research Grant Council of Hong Kong and the NIH; served on the Board of the Lupus Clinical Trials Consortium, Beacon Hill Villages, and Rx Foundation and advised the Institute for Clinical and Economic Review and the China Medical Board; previously had stock in Sequenom; and his spouse has stock in Johnson \& Johnson. H. C. M. is a current member of the CDC Workgroups and serves as a volunteer consultant on the American Academy of Pediatrics Committee on Infectious Diseases and the NIH DSMB. L. E. N. receives research funding from the NIH, Department of Defense, and the NIH Center for Research Resources and for Advancing Translational Sciences (NCATS), Global Lyme Alliance, and Peabody Foundation; serves on the Editorial Board for Annals of Emergency Medicine; has served as scientific consultant for Adaptive Technologies; and has received research funding from the NIH, Provider and 
Payer Quality Initiative (PPQI) Research Foundation, Harvard Catalyst, Hood Foundation, Bay Area Lyme Foundation, CDC, Emergency Medical Services for Children (EMSC), the National Patient-Centered Clinical Research Network (PCORNet), Milton Foundation, and Boston Children's Hospital. J. J. N. receives research funding from Bristol-Myers Squibb; serves as a member of the Subboard of Pediatric Rheumatology of the American Board of Pediatrics; and has received research funding from AbbVie, the NIH, and the Arthritis Foundation. A. A. P. has received research funding from Teva Pharmaceuticals and has served on the AAN Editorial Board of Neurology Clinical Practice. L. E. R. serves as a Council Member of the American College of Cardiology; has stock in Abbott, Proctor \& Gamble, and General Electric; has received Fellowship Support from Boston Scientific, Medtronic, and Abbott Laboratories (formerly St. Jude Medical); has received research funding from Boehringer Ingelheim Pharmaceuticals, Inc.; and has served on the Program Committee and the Patient and Caregivers Committee of the Heart Rhythm Society. J. R. has received research funding from the Center for AIDS Research, Biogen Idec, Hoffmann-LaRoche, Sun Pharmaceutical Industries Ltd., Genzyme, the Alzheimer's Association, and the American College of Radiology and has served as a speaker for Teva Pharmaceuticals. M. L. S. serves on the American Academy of Family Physicians (AAFP) Board of Directors, as an ex-officio board member of Delaware Academy of Family Physicians (DAFP), as the Chair of the Centers for Medicare and Medicaid Services (CMS) Advisory Panel on Outreach and Education, and as Secretary of the Board of Directors of the Association of Departments of Family Medicine; receives honoraria from the AAFP, DAFP, CMS, and Merck; has served on an Advisory Council for Highmark Health and as an advisor to the AAFP Adolescent Immunization Project; has received honoraria from the AAFP; and has served as the President of DAFP, as Editor of DelFamDoc, and as a member of AAFP Commissions. S. K. S. has received research funding from the $\mathrm{NIH}$ and has provided expert testimony for Danaher Lagnese, P.C. A. C. S. receives research funding from the $\mathrm{NIH}$ and the Mathers Foundation; has received research funding from the $\mathrm{NIH}$, the American College of Rheumatology, the Mathers Foundation, the English-Bonter-Mitchell Foundation, Immunetics, Inc., Zeus Diagnostics, and the Ounsworth-Fitzgerald Foundation; and has served as a scientific advisor for Baxter Bioscience Institute of Systems Biology, Immunetics, Inc., Roche Diagnostics, and Viramed. F. S. receives research funding from the Slovenian Research Agency; serves as the Head of Health Counsel of the Ministry of Health of the Republic of Slovenia and as a member of the Steering Committee for the European Society of Clinical Microbiology and Infectious Diseases Study Group for Lyme Borreliosis; serves on the Roche Diagnostics Advisory Board on Lyme Disease Diagnostics; and has received honoraria from Roche Diagnostics. R. S. receives research funding from the $\mathrm{NIH}$ and AbbVie, Inc.; serves as a content author and editor for UpToDate; provides expert testimony to Chin-Caplan, P.C.; has provided expert testimony for Conway Homer, P.C.; has served as an advisor for Paul Hastings, LLC; has served as a content editor for SimulConsult and as a Medical Education Resources lecturer for CME-granting educational courses; has received remuneration from SimulConsult as a coinvestigator for an $\mathrm{NIH}$-sponsored grant; and has received research funding from the NIH. J. T. receives research funding from the National Science Foundation, NIH, CDC, the Michigan Lyme Disease Association, and the Michigan Department of Health and Human Services; serves as a Scientific Council Advisor Member for the Canadian Lyme Disease Research Network and as a scientific advisor for the American Lyme Disease Association; has received research funding from Michigan State University; has served as an Associate Editor for Ticks and TickBorne Diseases and on the Tick Vectors, Surveillance, and Prevention Subcommittee of the US Department of Health and Human Services Tick-Borne Disease Working Group; and has received remuneration for providing educational seminars for Boehringer Ingelheim (formerly Merial). G. P. W. receives research funding from Immunetics, Inc., Rarecyte, Inc., Institute for Systems Biology, and Quidel Corporation; serves on the Board of the American Lyme Disease Foundation; provides and has previously provided expert testimony in malpractice cases; has stock in AbbVie, Inc., and Abbott Laboratories; has received research funding from the CDC, NIH, BioMérieux, Bio-Rad Laboratories, and DiaSorin, Inc; has served as a scientific research advisor for Baxter International and as a Lyme disease advisor and expert for the Missouri Board of Registration for the Healing Arts; has a patent approved (US patent no. 10,669,567 B2) for High Sensitivity Method for Early Lyme Disease Detection; filed 2 patent applications related to early Lyme disease detection (application no: 62/ 277,252) and Lyme arthritis and post-treatment Lyme disease syndrome (application no: 62/725,745); and has served on the Editorial Boards for Clinical Infectious Diseases, Vector-Borne and Zoonotic Diseases, and Ticks and Tick-Borne Diseases. L. S. Z. has served as an advisor for Novartis Promotional Speakers Bureau. No disclosures reported: K. B., R. R. B., V. L., M. C. O., J. R., E. E. V., and the 3 patient representatives. All authors have submitted the ICMJE Form for Disclosure of Potential Conflicts of Interest. Conflicts that the editors consider relevant to the content of the manuscript have been disclosed. Go to Neurology.org/ $\mathrm{N}$ for full disclosures.

\section{Publication History}

Received by Arthritis \& Rheumatology August 21, 2019. Accepted in final form June 5, 2020.

\begin{tabular}{lll} 
Appendix Authors & \\
\hline Name & Location & Contribution \\
\hline Paul M. & $\begin{array}{l}\text { Duke University } \\
\text { School of Medicine, } \\
\text { Durham, NC }\end{array}$ & $\begin{array}{l}\text { Substantial contributions to } \\
\text { study conception and design, } \\
\text { substantial contributions to } \\
\text { acquisition of data, substantial } \\
\text { contributions to analysis and } \\
\text { interpretation of data, drafting } \\
\text { the article or revising it critically } \\
\text { for important intellectual } \\
\text { content, and final approval of } \\
\text { the version of the article to be } \\
\text { published }\end{array}$ \\
&
\end{tabular}


Appendix (continued)

\begin{tabular}{|c|c|c|}
\hline Name & Location & Contribution \\
\hline $\begin{array}{l}\text { Jeffrey } \\
\text { Rumbaugh }\end{array}$ & $\begin{array}{l}\text { Pathway Neurology, } \\
\text { Tampa, FL }\end{array}$ & $\begin{array}{l}\text { Substantial contributions to study } \\
\text { conception and design, } \\
\text { substantial contributions to } \\
\text { acquisition of data, substantial } \\
\text { contributions to analysis and } \\
\text { interpretation of data, drafting } \\
\text { the article or revising it critically } \\
\text { for important intellectual content, } \\
\text { and final approval of the version } \\
\text { of the article to be published }\end{array}$ \\
\hline $\begin{array}{l}\text { Linda K. } \\
\text { Bockenstedt }\end{array}$ & $\begin{array}{l}\text { Yale University, New } \\
\text { Haven, CT }\end{array}$ & $\begin{array}{l}\text { Substantial contributions to study } \\
\text { conception and design, } \\
\text { substantial contributions to } \\
\text { acquisition of data, substantial } \\
\text { contributions to analysis and } \\
\text { interpretation of data, drafting } \\
\text { the article or revising it critically } \\
\text { for important intellectual content, } \\
\text { and final approval of the version } \\
\text { of the article to be published }\end{array}$ \\
\hline $\begin{array}{l}\text { Yngve T. } \\
\text { Falck-Ytter }\end{array}$ & $\begin{array}{l}\text { Case Western } \\
\text { Reserve University, } \\
\text { VA Northeast Ohio } \\
\text { Healthcare System, } \\
\text { Cleveland, OH }\end{array}$ & $\begin{array}{l}\text { Substantial contributions to } \\
\text { study conception and design, } \\
\text { substantial contributions to } \\
\text { acquisition of data, substantial } \\
\text { contributions to analysis and } \\
\text { interpretation of data, drafting } \\
\text { the article or revising it critically } \\
\text { for important intellectual content, } \\
\text { and final approval of the version } \\
\text { of the article to be published }\end{array}$ \\
\hline $\begin{array}{l}\text { Maria E. } \\
\text { Aguero- } \\
\text { Rosenfeld }\end{array}$ & $\begin{array}{l}\text { New York University } \\
\text { School of Medicine, } \\
\text { New York, NY }\end{array}$ & $\begin{array}{l}\text { Substantial contributions to } \\
\text { study conception and design, } \\
\text { substantial contributions to } \\
\text { acquisition of data, substantial } \\
\text { contributions to analysis and } \\
\text { interpretation of data, drafting } \\
\text { the article or revising it critically } \\
\text { for important intellectual content, } \\
\text { and final approval of the version } \\
\text { of the article to be published }\end{array}$ \\
\hline
\end{tabular}

\begin{tabular}{|c|c|c|}
\hline $\begin{array}{l}\text { Paul G. } \\
\text { Auwaerter }\end{array}$ & $\begin{array}{l}\text { Johns Hopkins } \\
\text { University School of } \\
\text { Medicine, Baltimore, } \\
\text { MD }\end{array}$ & $\begin{array}{l}\text { Substantial contributions to } \\
\text { study conception and design, } \\
\text { substantial contributions to } \\
\text { acquisition of data, substantial } \\
\text { contributions to analysis and } \\
\text { interpretation of data, drafting } \\
\text { the article or revising it critically } \\
\text { for important intellectual content, } \\
\text { and final approval of the version } \\
\text { of the article to be published }\end{array}$ \\
\hline Kelly Baldwin & $\begin{array}{l}\text { Geisinger Medical } \\
\text { Center, Danville, PA }\end{array}$ & $\begin{array}{l}\text { Substantial contributions to } \\
\text { study conception and design, } \\
\text { substantial contributions to } \\
\text { acquisition of data, substantial } \\
\text { contributions to analysis and } \\
\text { interpretation of data, drafting } \\
\text { the article or revising it critically } \\
\text { for important intellectual content, } \\
\text { and final approval of the version } \\
\text { of the article to be published }\end{array}$ \\
\hline $\begin{array}{l}\text { Raveendhara } \\
\text { R. Bannuru }\end{array}$ & $\begin{array}{l}\text { Tufts Medical } \\
\text { Center, Boston, MA }\end{array}$ & $\begin{array}{l}\text { Substantial contributions to } \\
\text { study conception and design, } \\
\text { substantial contributions to } \\
\text { acquisition of data, substantial } \\
\text { contributions to analysis and } \\
\text { interpretation of data, drafting } \\
\text { the article or revising it critically } \\
\text { for important intellectual content, } \\
\text { and final approval of the version } \\
\text { of the article to be published }\end{array}$ \\
\hline
\end{tabular}

Appendix (continued)

\begin{tabular}{|c|c|c|}
\hline Name & Location & Contribution \\
\hline $\begin{array}{l}\text { Kiran K. } \\
\text { Belani }\end{array}$ & $\begin{array}{l}\text { Childrens Hospital } \\
\text { and Clinical of } \\
\text { Minnesota, } \\
\text { Minneapolis, MN }\end{array}$ & $\begin{array}{l}\text { Substantial contributions to } \\
\text { study conception and design, } \\
\text { substantial contributions to } \\
\text { acquisition of data, substantial } \\
\text { contributions to analysis and } \\
\text { interpretation of data, drafting } \\
\text { the article or revising it critically } \\
\text { for important intellectual content, } \\
\text { and final approval of the version } \\
\text { of the article to be published }\end{array}$ \\
\hline $\begin{array}{l}\text { William R. } \\
\text { Bowie }\end{array}$ & $\begin{array}{l}\text { University of British } \\
\text { Columbia, } \\
\text { Vancouver, Canada }\end{array}$ & $\begin{array}{l}\text { Substantial contributions to } \\
\text { study conception and design, } \\
\text { substantial contributions to } \\
\text { acquisition of data, substantial } \\
\text { contributions to analysis and } \\
\text { interpretation of data, drafting } \\
\text { the article or revising it critically } \\
\text { for important intellectual content, } \\
\text { and final approval of the version } \\
\text { of the article to be published }\end{array}$ \\
\hline $\begin{array}{l}\text { John A. } \\
\text { Branda }\end{array}$ & $\begin{array}{l}\text { Massachusetts } \\
\text { General Hospital, } \\
\text { Boston, MA }\end{array}$ & $\begin{array}{l}\text { Substantial contributions to } \\
\text { study conception and design, } \\
\text { substantial contributions to } \\
\text { acquisition of data, substantial } \\
\text { contributions to analysis and } \\
\text { interpretation of data, drafting } \\
\text { the article or revising it critically } \\
\text { for important intellectual content, } \\
\text { and final approval of the version } \\
\text { of the article to be published }\end{array}$ \\
\hline $\begin{array}{l}\text { David B. } \\
\text { Clifford }\end{array}$ & $\begin{array}{l}\text { Washington } \\
\text { University School of } \\
\text { Medicine, St. Louis, } \\
\text { MO }\end{array}$ & $\begin{array}{l}\text { Substantial contributions to } \\
\text { study conception and design, } \\
\text { substantial contributions to } \\
\text { acquisition of data, substantial } \\
\text { contributions to analysis and } \\
\text { interpretation of data, drafting } \\
\text { the article or revising it critically } \\
\text { for important intellectual content, } \\
\text { and final approval of the version } \\
\text { of the article to be published }\end{array}$ \\
\hline $\begin{array}{l}\text { Francis J. } \\
\text { DiMario Jr }\end{array}$ & $\begin{array}{l}\text { Connecticut } \\
\text { Children's Medical } \\
\text { Center, Hartford, CT }\end{array}$ & $\begin{array}{l}\text { Substantial contributions to } \\
\text { study conception and design, } \\
\text { substantial contributions to } \\
\text { acquisition of data, substantial } \\
\text { contributions to analysis and } \\
\text { interpretation of data, drafting } \\
\text { the article or revising it critically } \\
\text { for important intellectual content, } \\
\text { and final approval of the version } \\
\text { of the article to be published }\end{array}$ \\
\hline $\begin{array}{l}\text { John J. } \\
\text { Halperin }\end{array}$ & $\begin{array}{l}\text { Atlantic Health } \\
\text { System, Summit, NJ }\end{array}$ & $\begin{array}{l}\text { Substantial contributions to } \\
\text { study conception and design, } \\
\text { substantial contributions to } \\
\text { acquisition of data, substantial } \\
\text { contributions to analysis and } \\
\text { interpretation of data, drafting } \\
\text { the article or revising it critically } \\
\text { for important intellectual content, } \\
\text { and final approval of the version } \\
\text { of the article to be published }\end{array}$ \\
\hline $\begin{array}{l}\text { Peter J. } \\
\text { Krause }\end{array}$ & $\begin{array}{l}\text { Yale School of Public } \\
\text { Health, New Haven, } \\
\text { CT }\end{array}$ & $\begin{array}{l}\text { Substantial contributions to } \\
\text { study conception and design, } \\
\text { substantial contributions to } \\
\text { acquisition of data, substantial } \\
\text { contributions to analysis and } \\
\text { interpretation of data, drafting } \\
\text { the article or revising it critically } \\
\text { for important intellectual content, } \\
\text { and final approval of the version } \\
\text { of the article to be published }\end{array}$ \\
\hline
\end{tabular}

Continued 
Appendix (continued)

\begin{tabular}{ll}
\hline Name & Location \\
\hline $\begin{array}{l}\text { Valery } \\
\text { Lavergne }\end{array}$ & $\begin{array}{l}\text { University of } \\
\text { Montreal, Quebec, } \\
\text { Canada }\end{array}$
\end{tabular}

Contribution

Substantial contributions to

study conception and design,

substantial contributions to

acquisition of data, substantial contributions to analysis and

interpretation of data, drafting

the article or revising it critically

for important intellectual content, and final approval of the version of the article to be published

\begin{tabular}{ll}
\hline Matthew H. & Brigham and \\
Liang & Women's Hospital, \\
& Boston, MA
\end{tabular}

Substantial contributions to study conception and design, substantial contributions to acquisition of data, substantial contributions to analysis and interpretation of data, drafting the article or revising it critically for important intellectual content, and final approval of the version of the article to be published

\begin{tabular}{lll}
\hline H. Cody & Tufts Medical & Substantial contributions to \\
Meissner & Center, Boston, MA & study conception and design,
\end{tabular}
substantial contributions to acquisition of data, substantial contributions to analysis and interpretation of data, drafting the article or revising it critically for important intellectual content, and final approval of the version of the article to be published

Lise E. Boston Children's Substantial contributions to

Nigrovic Hospital, study conception and design,
MA substantial contributions to acquisition of data, substantial contributions to analysis and interpretation of data, drafting the article or revising it critically for important intellectual content, and final approval of the version of the article to be published

\begin{tabular}{lll}
\hline James (Jay) J. & Medical College of & Substantial contributions to \\
Nocton & Wisconsin, & study conception and design,
\end{tabular}
Waowatosa, WI substantial contributions to acquisition of data, substantial contributions to analysis and interpretation of data, drafting the article or revising it critically for important intellectual content, and final approval of the version of the article to be published

\begin{tabular}{ll}
\hline Mikala C. & Tufts Medical \\
Osani & Center, Boston, MA
\end{tabular}

Substantial contributions to study conception and design, substantial contributions to acquisition of data, substantial contributions to analysis and interpretation of data, drafting the article or revising it critically for important intellectual content, and final approval of the version of the article to be published

\begin{tabular}{lll}
\hline Amy A. Pruitt & $\begin{array}{l}\text { University of } \\
\text { Pennsylvania, } \\
\text { Philadelphia, PA }\end{array}$ & $\begin{array}{l}\text { Substantial contributions to } \\
\text { study conception and design, } \\
\text { substantial contributions to } \\
\text { acquisition of data, substantial } \\
\text { contributions to analysis and } \\
\text { interpretation of data, drafting } \\
\text { the article or revising it critically } \\
\text { for important intellectual content, } \\
\text { and final approval of the version } \\
\text { of the article to be published }\end{array}$ \\
\end{tabular}

Appendix (continued)

\begin{tabular}{|c|c|c|}
\hline Name & Location & Contribution \\
\hline Jane Rips & $\begin{array}{l}\text { Consumer } \\
\text { Representative, } \\
\text { Omaha, NE }\end{array}$ & $\begin{array}{l}\text { Substantial contributions to } \\
\text { study conception and design, } \\
\text { substantial contributions to } \\
\text { analysis and interpretation of } \\
\text { data, drafting the article or } \\
\text { revising it critically for important } \\
\text { intellectual content, and final } \\
\text { approval of the version of the } \\
\text { article to be published }\end{array}$ \\
\hline $\begin{array}{l}\text { Lynda E. } \\
\text { Rosenfeld }\end{array}$ & $\begin{array}{l}\text { Yale University, New } \\
\text { Haven, CT }\end{array}$ & $\begin{array}{l}\text { Substantial contributions to } \\
\text { study conception and design, } \\
\text { substantial contributions to } \\
\text { acquisition of data, substantial } \\
\text { contributions to analysis and } \\
\text { interpretation of data, drafting } \\
\text { the article or revising it critically } \\
\text { for important intellectual content, } \\
\text { and final approval of the version } \\
\text { of the article to be published }\end{array}$ \\
\hline $\begin{array}{l}\text { Margot L. } \\
\text { Savoy }\end{array}$ & $\begin{array}{l}\text { Temple University, } \\
\text { Philadelphia, PA }\end{array}$ & $\begin{array}{l}\text { Substantial contributions to } \\
\text { study conception and design, } \\
\text { substantial contributions to } \\
\text { acquisition of data, substantial } \\
\text { contributions to analysis and } \\
\text { interpretation of data, drafting } \\
\text { the article or revising it critically } \\
\text { for important intellectual content, } \\
\text { and final approval of the version } \\
\text { of the article to be published }\end{array}$ \\
\hline Sunil K. Sood & $\begin{array}{l}\text { Northwell Health, } \\
\text { Manhattan, NY }\end{array}$ & $\begin{array}{l}\text { Substantial contributions to } \\
\text { study conception and design, } \\
\text { substantial contributions to } \\
\text { acquisition of data, substantial } \\
\text { contributions to analysis and } \\
\text { interpretation of data, drafting } \\
\text { the article or revising it critically } \\
\text { for important intellectual content, } \\
\text { and final approval of the version } \\
\text { of the article to be published }\end{array}$ \\
\hline $\begin{array}{l}\text { Allen C. } \\
\text { Steere }\end{array}$ & $\begin{array}{l}\text { Massachusetts } \\
\text { General Hospital, } \\
\text { Boston, MA }\end{array}$ & $\begin{array}{l}\text { Substantial contributions to } \\
\text { study conception and design, } \\
\text { substantial contributions to } \\
\text { acquisition of data, substantial } \\
\text { contributions to analysis and } \\
\text { interpretation of data, drafting } \\
\text { the article or revising it critically } \\
\text { for important intellectual content, } \\
\text { and final approval of the version } \\
\text { of the article to be published }\end{array}$ \\
\hline Franc Strle & $\begin{array}{l}\text { University Medical } \\
\text { Centre Ljubljana, } \\
\text { Slovenia }\end{array}$ & $\begin{array}{l}\text { Substantial contributions to } \\
\text { study conception and design, } \\
\text { substantial contributions to } \\
\text { acquisition of data, substantial } \\
\text { contributions to analysis and } \\
\text { interpretation of data, drafting } \\
\text { the article or revising it critically } \\
\text { for important intellectual } \\
\text { content, and final approval of } \\
\text { the version of the article to be } \\
\text { published }\end{array}$ \\
\hline $\begin{array}{l}\text { Robert } \\
\text { Sundel }\end{array}$ & $\begin{array}{l}\text { Boston Children's } \\
\text { Hospital, MA }\end{array}$ & $\begin{array}{l}\text { Substantial contributions to } \\
\text { study conception and design, } \\
\text { substantial contributions to } \\
\text { acquisition of data, substantial } \\
\text { contributions to analysis and } \\
\text { interpretation of data, drafting } \\
\text { the article or revising it critically } \\
\text { for important intellectual content, } \\
\text { and final approval of the version } \\
\text { of the article to be published }\end{array}$ \\
\hline
\end{tabular}




\begin{tabular}{|c|c|c|}
\hline \multicolumn{3}{|c|}{ Appendix (continued) } \\
\hline Name & Location & Contribution \\
\hline Jean Tsao & $\begin{array}{l}\text { Michigan State } \\
\text { University, East } \\
\text { Lansing, MI }\end{array}$ & $\begin{array}{l}\text { Substantial contributions to } \\
\text { study conception and design, } \\
\text { substantial contributions to } \\
\text { acquisition of data, substantial } \\
\text { contributions to analysis and } \\
\text { interpretation of data, drafting } \\
\text { the article or revising it critically } \\
\text { for important intellectual content, } \\
\text { and final approval of the version } \\
\text { of the article to be published }\end{array}$ \\
\hline $\begin{array}{l}\text { Elizaveta E. } \\
\text { Vaysbrot }\end{array}$ & $\begin{array}{l}\text { Tufts Medical } \\
\text { Center, Boston, MA }\end{array}$ & $\begin{array}{l}\text { Substantial contributions to } \\
\text { study conception and design, } \\
\text { substantial contributions to } \\
\text { acquisition of data, substantial } \\
\text { contributions to analysis and } \\
\text { interpretation of data, drafting } \\
\text { the article or revising it critically } \\
\text { for important intellectual content, } \\
\text { and final approval of the version } \\
\text { of the article to be published }\end{array}$ \\
\hline $\begin{array}{l}\text { Gary P. } \\
\text { Wormser }\end{array}$ & $\begin{array}{l}\text { New York Medical } \\
\text { College, Valhalla, NY }\end{array}$ & $\begin{array}{l}\text { Substantial contributions to } \\
\text { study conception and design, } \\
\text { substantial contributions to } \\
\text { acquisition of data, substantial } \\
\text { contributions to analysis and } \\
\text { interpretation of data, drafting } \\
\text { the article or revising it critically } \\
\text { for important intellectual } \\
\text { content, and final approval of } \\
\text { the version of the article to be } \\
\text { published }\end{array}$ \\
\hline
\end{tabular}

\begin{tabular}{lll} 
Appendix & (continued) & \\
\hline Name & Location & Contribution \\
\hline Lawrence S. & $\begin{array}{l}\text { Connecticut } \\
\text { Children's Medical } \\
\text { Center, Hartford, CT }\end{array}$ & $\begin{array}{l}\text { Substantial contributions to } \\
\text { study conception and design, } \\
\text { substantial contributions to } \\
\text { acquisition of data, substantial } \\
\text { contributions to analysis and } \\
\text { interpretation of data, drafting } \\
\text { the article or revising it critically } \\
\text { for important intellectual } \\
\text { content, and final approval of } \\
\text { the version of the article to be } \\
\text { published }\end{array}$ \\
\hline
\end{tabular}

\section{References}

1. Guyatt GH, Oxman AD, Vist GE, et al. GRADE Working Group. GRADE: an emerging consensus on rating quality of evidence and strength of recommendations. BMJ 2008;336:924-926.

2. Schunemann H, Oxman AG, Gordon GH. Handbook for Grading the Quality of Evidence and the Strength of Recommendations Using the GRADE Approach. Hamilton: GRADEpro, 2015. Available at: gdt.gradepro.org/app/handbook/handbook.html. Accessed 13 May 2019.

3. Luft BJ, Dattwyler RJ, Johnson RC, et al. Azithromycin compared with amoxicillin in the treatment of erythema migrans: a double-blind, randomized, controlled trial. Ann Intern Med 1996;124:785-791.

4. Feder HM Jr, Hoss DM, Zemel L, Telford SR III, Dias F, Wormser GP. Southern tick-associated rash illness (STARI) in the North: STARI following a tick bite in Long Island, New York. Clin Infect Dis 2011;53:e142-e146.

5. Wormser GP, Masters E, Nowakowski J, et al. Prospective clinical evaluation of patients from Missouri and New York with erythema migrans-like skin lesions. Clin Infect Dis 2005;41:958-965.

6. Baugh RF, Basura GJ, Ishii LE, et al. Clinical practice guideline: bell's palsy executive summary. Otolaryngol Head Neck Surg 2013;149:656-663.

\section{NEW EPISODE}

(ค)

$\underset{\text { PODCAST }}{\text { Neurology }}$

February 9, 2021
Clinical Practice Guidelines by the Infectious Diseases Society of America, American Academy of Neurology, and American College of Rheumatology: 2020 Guidelines for the Prevention, Diagnosis and Treatment of Lyme Disease (see p. 262)

In the first segment, Dr. Jason Crowell talks with Dr. Jeffrey Rumbaugh about the latest Lyme Disease Guidelines. In the second part of the podcast, Dr. Fabio Nascimento talks with Dr. Elizabeth Thiele in the second of a 4-part series called "Update in Epilepsy."

Disclosures can be found at Neurology.org.

CME Opportunity: Listen to this week's Neurology ${ }^{\circledR}$ Podcast and earn 0.5 AMA PRA Category 1 CME Credits ${ }^{\mathrm{TM}}$ by completing the online podcast quiz. 


\section{Neurology}

Clinical Practice Guidelines by the Infectious Diseases Society of America, American Academy of Neurology, and American College of Rheumatology: 2020 Guidelines for the Prevention, Diagnosis, and Treatment of Lyme Disease

Paul M. Lantos, Jeffrey Rumbaugh, Linda K. Bockenstedt, et al.

Neurology 2021;96;262-273 Published Online before print November 30, 2020

DOI 10.1212/WNL.0000000000011151

This information is current as of November 30, 2020

$\begin{array}{ll}\begin{array}{l}\text { Updated Information \& } \\ \text { Services }\end{array} & \begin{array}{l}\text { including high resolution figures, can be found at: } \\ \text { http://n.neurology.org/content/96/6/262.full }\end{array} \\ \text { References } & \begin{array}{l}\text { This article cites } 5 \text { articles, } 1 \text { of which you can access for free at: } \\ \text { http://n.neurology.org/content/96/6/262.full\#ref-list-1 }\end{array} \\ \text { An erratum has been published regarding this article. Please see next page or: } & \text { /content/96/6/296.full.pdf } \\ \text { Information about reproducing this article in parts (figures,tables) or in its entirety can be } \\ \text { found online at: } \\ \text { http://www.neurology.org/about/about_the_journal\#permissions } \\ \text { Information about ordering reprints can be found online: } \\ \text { http://n.neurology.org/subscribers/advertise }\end{array}$

Neurology $®$ is the official journal of the American Academy of Neurology. Published continuously since 1951, it is now a weekly with 48 issues per year. Copyright (C) 2020 American Academy of Neurology. All rights reserved. Print ISSN:

0028-3878. Online ISSN: 1526-632X.

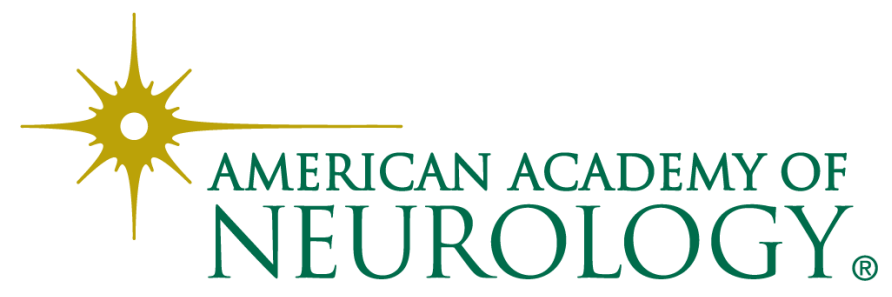




\title{
Disputes \& Debates: Editors' Choice
}

Steven Galetta, MD, FAAN, Section Editor

\section{Editors' Note: Evaluation of Efficacy and Tolerability of First-Line Therapies in NMOSD}

In the article, "Evaluation of Efficacy and Tolerability of First-Line Therapies in NMOSD," Dr. Poupart et al. compared the efficacy and risk of severe infectious events of immunosuppressive agents used early as first-line therapy in patients with neuromyelitis optica spectrum disorder (NMOSD). Among 136 patients, they found that the use of first-line rituximab seemed more effective than mycophenolate mofetil (MMF) in suppressing clinical activity, independent of the antibody status. In response, Dr. Leite notes that rituximab is currently used as second-line therapy in most countries, but because rituximab and MMF have similar tolerability but rituximab had superior efficacy, an argument could be made for considering rituximab as a first-line therapy. In addition to noting that the apparent similarity in efficacy of rituximab and azathioprine was unexpected and contradicts other studies, Dr. Leite raises a couple of concerns about rituximab, including (1) rituximab-associated hypogammaglobulinemia (assessment of which would require analyses of plasma immunoglobulin levels) and (2) potential differences in the role of rituximab for chronic management between NMOSD patients with aquaporin-4 (AQP4) antibodies vs myelin oligodendrocyte (MOG) antibodies, who were analyzed together in this study. Responding to these comments, the authors note the small sample size of the azathioprine group, which limited statistical power. They also report that $22.7 \%$ of 44 patients treated with rituximab who had immunoglobulin results available met their definition of hypogammaglobulinemia, with one such patient having a serious infection. They agree that MOG and AQP4 diseases are different processes but note that they chose to focus on the broader NMOSD phenotype because the optimal management of MOG-positive patients is also uncertain. The authors note that there was no significant difference in therapeutic response based on the antibody status. This exchange highlights the need to further examine the commonly used treatment regimens for NMOSD in controlled trials, both in those that are MOG positive and those that harbor AQP4 antibodies.

\section{Reader Response: Evaluation of Efficacy and Tolerability of First-Line Therapies in NMOSD}

\author{
M. Isabel Leite (Oxford, UK) \\ Neurology ${ }^{\circledR} 2021 ; 96: 294-295$. doi:10.1212/WNL.0000000000011401
}

I read with interest the article by Poupart et al. ${ }^{1}$ It reports the efficacy and tolerability of first-line immunotherapy in 136 patients with neuromyelitis optica spectrum disorder (NMOSD) with antibodies (Abs) against aquaporin-4 (AQP4, AQP4-Abs) or myelin oligodendrocyte (MOG, MOG-Abs).

The authors show the effect of first-line rituximab (RTX), which is used as second-line therapy in most countries. RTX shows superiority in efficacy compared with mycophenolate mofetil (MMF); azathioprine (AZA)-treated patients have responded as efficiently as those on RTX, 
which contradicts other studies (see table 4). However, looking at figure 2, it seems that, in the long-term, RTX remains the best of the 3 immunotherapies.

Knowing that the tolerability of RTX and MMF is similar and probably acceptable, one wonders whether RTX should-more often-be considered first-line immunotherapy for patients with NMOSD. However, concerns may be raised regarding 2 distinct issues, which this study could have addressed.

First, on hypogammaglobulinemia in RTX-treated patients: RTX-associated hypogammaglobulinemia has been reported widely, ${ }^{2,3}$ but most of the studies include patients on long-term RTX and often on other concurrent or previous immunosuppressive agents. Missing is the analysis of the plasma immunoglobulin levels - particularly in RTX-treated patients_even knowing that this is a retrospective study.

Second, on treating unnecessarily MOG-Ab patients with RTX, the authors analyzed together both $\mathrm{AQP} 4 \mathrm{Ab}$ and MOG-Ab subgroups, when there is increasing evidence that these two conditions are distinct. ${ }^{4}$ Therefore, their chronic management requirements may be different. It would be of value to explore - in depth and for longer - the efficacy of first-line RTX in AQP-4-Ab patients.

1. Poupart J, Giovannelli J, Deschamps R, et al.. Evaluation of efficacy and tolerability of first-line therapies in NMOSD. Neurology 2020; 94:e1645-e1656.

2. Barmettler S, Ong MS, Farmer JR, Choi H, Walter J. Association of immunoglobulin levels, infectious risk, and mortality with rituximab and hypogammaglobulinemia. JAMA Netw Open 2018;1:e184169.

3. Christou EAA, Giardino G, Worth A, Ladomenou F. Risk factors predisposing to the development of hypogammaglobulinemia and infections post-Rituximab. Int Rev Immunol 2017;36:352-359.

4. Leite MI, Sato DK. MOG-antibody-associated disease is different from MS and NMOSD and should be considered as a distinct disease entity-yes. Mult Scler 2020;26:272-274.

Copyright (c) 2021 American Academy of Neurology

\section{Author Response: Evaluation of Efficacy and Tolerability of First-Line Therapies in NMOSD}

Helene Zephir (Lille, France), Julien Poupart (Lille, France), Romain Deschamps (Paris), Bertrand Audoin (Marseille, France), Jonathan Ciron (Toulouse, France), Elisabeth Maillart (Paris), Caroline Papeix (Paris), Nicolas Collongues (Strasbourg, France), Bertrand Bourre (Rouen, France), Mickaël Cohen (Nice, France), Sandrine Wiertlewski (Nantes, France), Olivier Outteryck (Lille, France), David Laplaud (Nantes, France), Sandra Vukusic (Lyon, France), Romain Marignier (Lyon, France), and Jonathan Giovannelli (Lille, France) Neurology ${ }^{\circledR}$ 2021;96:295-296. doi:10.1212/WNL.0000000000011403

We thank Maria Isabel Leite for her comments on our article. ${ }^{1}$

First, from this observational study, regarding the risk of relapse for azathioprine (AZA) vs rituximab (RTX), we can only state that we did not observe any difference by interpreting a nonsignificant result. Moreover, the effect size was similar to those observed in other studies. We pointed out the small size of the AZA group $(n=23)$, which led to a low statistical power. Second, we can provide some data on hypogammaglobulinemia - as defined with immunoglobulin G (IgG) level $<6 \mathrm{~g} / \mathrm{L}^{2}$-in 44/62 RTX-treated patients. Among them, 10 patients $(22.7 \%)$ presented hypogammaglobulinemia $($ mean $[\mathrm{SD}]=4.2[2] \mathrm{g} / \mathrm{L})$. Five patients had a serious infectious disease, but the information on hypogammaglobulinemia was available in 3 patients. Among them, one had hypogammaglobulinemia. Because the data were partial, these results should be interpreted with caution. Third, we agree that antimyelin oligodendrocyte glycoprotein (MOG) and antiaquaporin-4 (AQP4) diseases reflect different pathologic processes. ${ }^{3}$ Considering that the right treatment strategy in patients with anti-MOG remains unsolved, we focused on NMOSD phenotype either with anti-AQP4 or anti-MOG antibodies. For the specific question addressed in the article, the interaction test was not significant, 
meaning that no difference of therapeutic response level to the different antibody status was observed. We also conducted statistical analysis only in patients with anti-AQP4. We agree that in the issue addressing the best first-line strategy in NMOSD, this study probably contributes more to the perspective of anti-AQP4 NMOSD patients ${ }^{4}$ than anti-MOG in general.

1. Poupart J, Giovannelli J, Deschamps R, et al. Evaluation of efficacy and tolerability of first-line therapies in NMOSD. Neurology 2020; 94:e1645-e1656.

2. Stabler S, Giovannelli J, Launay D, et al. Serious infectious events and immunoglobulin replacement therapy in patients with autoimmune diseases receiving rituximab: a retrospective cohort study. Clin Infect Dis 2020; Feb 18:ciaa127.doi:10.1093/cid/ciaa127.

3. Leite MI, Sato DK. MOG-antibody-associated disease is different from MS and NMOSD and should be considered as a distinct disease entity - Yes. Mult Scler 2020;26:272-274.

4. Zéphir H, Bernard-Valnet R, Lebrun C, et al. Rituximab as first-line therapy in neuromyelitis optica: efficiency and tolerability. J Neurol 2015;262:2329-2335.

Copyright (c) 2021 American Academy of Neurology

CORRECTION

\section{Clinical Practice Guidelines by the Infectious Diseases Society of America, American Academy of Neurology, and American College of Rheumatology}

2020 Guidelines for the Prevention, Diagnosis and Treatment of Lyme Disease

Neurology ${ }^{\circledR} 2021 ; 96: 296$. doi:10.1212/WNL.0000000000011422

In the first online publication of Special Article "Clinical Practice Guidelines by the Infectious Diseases Society of America, American Academy of Neurology, and American College of Rheumatology: 2020 Guidelines for the Prevention, Diagnosis and Treatment of Lyme Disease" by Lantos et al. ${ }^{1}$ on November 30, 2020, the abstract was erroneously omitted by Clinical Infectious Diseases production staff. The following abstract has been added to the final published version of the guideline:

This evidence-based clinical practice guideline for the prevention, diagnosis, and treatment of Lyme disease was developed by a multidisciplinary panel representing the Infectious Diseases Society of America (IDSA), the American Academy of Neurology (AAN), and the American College of Rheumatology (ACR). The scope of this guideline includes prevention of Lyme disease, and the diagnosis and treatment of Lyme disease presenting as erythema migrans, Lyme disease complicated by neurologic, cardiac, and rheumatologic manifestations, Eurasian manifestations of Lyme disease, and Lyme disease complicated by coinfection with other tickborne pathogens. This guideline does not include comprehensive recommendations for babesiosis and tick-borne rickettsial infections, which are published in separate guidelines. The target audience for this guideline includes primary care physicians and specialists caring for this condition such as infectious diseases specialists, emergency physicians, internists, pediatricians, family physicians, neurologists, rheumatologists, cardiologists and dermatologists in North America.

Oxford University Press regrets the omission.

The first online publication on November 30, 2020, also included an incorrect web address and hyperlink for the full-length guideline. The web address should have read, "aan.com/Guidelines/home/GuidelineDetail/1015," and linked to an.com/Guidelines/home/GuidelineDetail/ 1015. The final published version of the guideline includes the correct web address and hyperlink. The AAN Guideline Publications Staff regret the error.

\section{Reference}

1. Lantos PM, Rumbaugh J, Bockenstedt LK, et al. Clinical practice guidelines by the Infectious Diseases Society of America, American Academy of Neurology, and American College of Rheumatology: 2020 guidelines for the prevention, diagnosis, and treatment of Lyme disease. Neurology 2021;96:262-273. 